\title{
Bacterial carbon production in the northern Baltic: a comparison of thymidine incorporation and FDC based methods
}

\author{
Pirjo Tuomi* \\ Finnish Environment Institute, PO Box 140, FIN-00251 Helsinki, Finland
}

\begin{abstract}
Bacterial production in the open Gulf of Finland was estimated by ${ }^{3} \mathrm{H}$-thymidine incorporation rate (TTI) and by the frequency of dividing cells (FDC), counted by transmission electron microscopy (TEM). To relate TTl and FDC to bacterial growth rate, batch cultures with the natural bacterial communty from the study area were used. Conversion factors between 0.2 and $7.2 \times 10^{18}$ cells

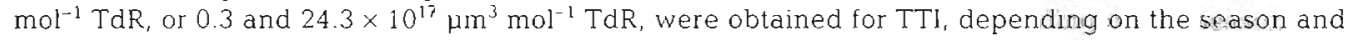
calculation model used (integrative, cumulative, or modified derivative). From FDC and growth rate $(\mu)$ based on bacterial cell numbers, the following equation was derived: $\mu=0.002$ FDC -0.001 Bacterial carbon production in the study area, estimated using the FDC method, was 20 to $80 \%$ higher than TTIbased estimates. Virus abundances were followed in the batch cultures and in the field study. Viral lysis may have been a significant cause of bacterial mortality in the field, but it remains to be shown whether viral-induced mortality was already included in the empirical conversion factor.
\end{abstract}

KEY WORDS: Bacteria ${ }^{3} \mathrm{H}$-thymidine incorporation rate Frequency of dividing cells Baltic

\section{INTRODUCTION}

Bacterial production in aquatic ecosystems is often estimated from the incorporation rate of tritiated thymidine (TTI) into bacterial DNA (Fuhrman \& Azam $1980,1982)$. Several conversion factors, ranging from 1 to $60 \times 10^{18}$ cells $\mathrm{mol}^{-1}$ thymidine incorporated, have been published for the conversion of TTI into cell production rate (references in Bell 1988). The conversion factors are derived from batch cultures of filtered bacterial communities by calculating the ratio between the increase in cell abundance and TTI. Different models can be used in the calculations. The integrative method (method 1) derives the conversion factor from the total amount of cells produced and the amount of thymidine incorporated over the incubation time (Fuhrman \& Azam 1980), while the other methods use linear regressions of either one or both parameters, as an estimate of cells produced, against thymidine incor-

\footnotetext{
·E-mail: pirjo.tuomı@vyh.fi
}

porated. In the cumulative method (Method 2) a linear regression of cell abundance against cumulative TTI is used (Bjornsen \& Kuparinen 1991), whereas the derivative method fits a linear regression of TTI to the initial cell abund.ance (Kirchman et al. 1982). These methods should give equal conversion factors, if cell abundance and TTI increase at the same rate. As this is often not the case, Ducklow et al. (1992) have modified the derivative method (Method 3) by using regressions of both cell abundance and TTI.

The use of the frequency of dividing cells (FDC) to estimate bacterial production has the great advantage of not requiring incubation of the samples (Hagström et al. 1979), but the disadvantage is in the difficulty of observing dividing cells when counted with epifluorescence microscopy. The frequency of bacterial cells in the division stage is supposed to reflect the average growth rate $(\mu)$ of the bacterial community, but the conversion equations for $\mu$ from FDC are not well established for the natural bacterial communities and so the FDC method has not been widely used. 
The aim of this study was to compare the efficacy of using thymidine incorporation rate (Fuhrman \& Azam 1980, 1982) and FDC (Hagström et al. 1979) in the estimation of bacterial cell production. Bacterial cells were counted with transmission electron microscopy (TEM), with which dividing cells are easily seen. Using batch cultures with natural bacterial communities, the conversion factors for TTI, and the equation for FDC, were calculated empirically and applied to the data from a monitoring study carried out in the Gulf of Finland in 1994. In addition, the abundance of viruses in the batch cultures and in the field study was estimated, and their possible effect on bacterial production measurements is discussed below

\section{MATERIALS AND METHODS}

Sampling. This study was carried out from April to October 1994 at the entrance to the Gulf of Finland in the northern Baltic Sea, as part of a monitoring program of the coastai ecosysten. Water samples wero taken weekly at the fixed sampling station $\left(59^{\circ} 40.3^{\prime} \mathrm{N}\right.$, $23^{\circ} 14.5^{\prime} \mathrm{E}$ ) in the open sea zone. Pooled water samples were taken from the upper $5 \mathrm{~m}$ at $1 \mathrm{~m}$ intervals using a Ruttner type sampler. The samples were processed further in the laboratory.

Chlorophyll a. Subsamples for total chl a measurements (method modified from Marker et al. 1980) were filtered onto Whatman GF/F filters, sonicated for $10 \mathrm{~min}$ and soaked in $96 \%$ ethanol for $24 \mathrm{~h}$ at room temperature and in darkness. The extracts were filtered through Whatman GF/F filters and the chl a concentrations were measured with a Shimadzu RF-5001 spectrofluorometer, which was standardized using pure chl a (Sigma)

Batch cultures of natural bacterial communities. To determine the conversion factors for the 2 bacterial

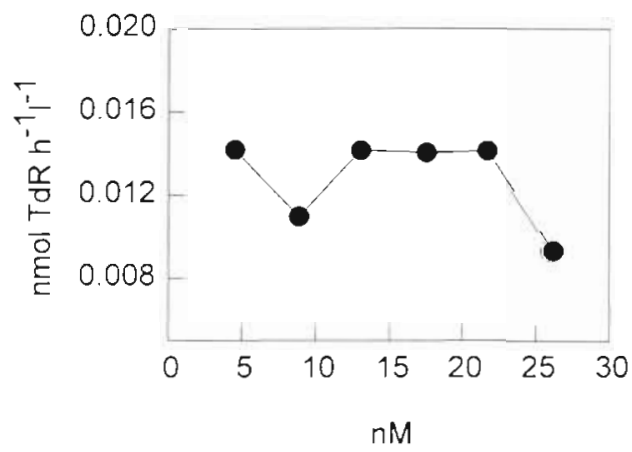

Fig. 1. Thymidine incorporation rate of the bacterial community on June 21 using a successively increasing thymidne concentration
Table 1. Summary of preparation and incubation of the batch cultures used in the conversion factor determinations. Time $(t)$ is the incubation time used for conversion factor calculations. Temperatures are given for both the experimental $(T)$ and the original sample (in situ $T$ )

\begin{tabular}{|lccccc|}
\hline Batch & $\begin{array}{c}\text { Pore size of filters for } \\
\text { inoculum } \\
\text { culture media }\end{array}$ & $t$ & $T$ & in situ $T$ \\
\hline June & $0.8 \mu \mathrm{m}$ & $0.1 \mu \mathrm{m}$ & $48 \mathrm{~h}$ & $12^{\circ} \mathrm{C}$ & $10^{\circ} \mathrm{C}$ \\
August & $1.0 \mu \mathrm{m}$ & $0.2 \mu \mathrm{m}$ & $65 \mathrm{~h}$ & $24^{\circ} \mathrm{C}$ & $20^{\circ} \mathrm{C}$ \\
September & $1.0 \mu \mathrm{m}$ & $0.2 \mu \mathrm{m}$ & $60 \mathrm{~h}$ & $18^{\circ} \mathrm{C}$ & $13^{\circ} \mathrm{C}$ \\
\hline
\end{tabular}

production methods, 2 parallel batch cultures were prepared on June 21, August 2 and September 18 by diluting a $400 \mathrm{ml}$ inoculum in $1600 \mathrm{ml}$ of culture medium. Filtration of the sample water for the inoculum and culture media as well as incubation of the batch cultures are shown in Table 1 Bacteria were grown for 60 to $96 \mathrm{~h}$ in the dark. Subsamples for production measurements and microscopy were taken every $12 \mathrm{~h}$.

Thymidine incorporation rate. Thymidine incorporation was assayed (Fuhrman \& Azam 1980, 1982) from $10 \mathrm{ml}$ subsamples ( 1 blank and 2 replicates) drawn from the seawater samples or batch cultures, and transferred to glass vials. The blanks were killed with formalin (final conc. $0.4 \%$ formaldehyde), and ${ }^{3} \mathrm{H}$ labeled thymidine ( 44 to $49 \mathrm{Ci} \mathrm{mmol}^{-1}$, Amersham) was added at saturation level (Fig. 1) (final conc. used 10 to $11 \mathrm{nM}$ ). Incubations of the field study samples were done at in situ temperatures $\left( \pm 2^{\circ} \mathrm{C}\right)$ and of the batch cultures at culture temperature (Table 1). Incubations were terminated after 30 to $60 \mathrm{~min}$ by adding formalin (final conc. $0.4 \%$ formaldehyde). The labeled material was collected by cold TCA extraction (final conc. $5 \%$ ) and filtered onto $0.2 \mu \mathrm{m}$ nitrate cellulose filters (Sartorius). The filters were dissolved in Hisafe liquid scintillation cocktail (Wallac, Turku, Finland), and radioactivity was measured by liquid scintillation. counting (LKB Rackbeta 1216, Wallac) using the external standard channels ratio method

Microscopy. Total bacterial counts, FDC values, cell volume measurements and total viral counts were made from an $80 \mathrm{ml}$ subsample fixed with $25 \%$ EM grade glutaraldehyde (final conc. $1 \%$ ) and harvested by centrifugation |Beckman rotor SW 28, 2 h, $26000 \mathrm{rpm}(115000 \times \mathrm{g})]$ onto 400 mesh Ni grids with carbon coated Pioloform film according to Bratbak \& Heldal (1993). The bacteria and the viruses were counted at 20000 and $100000 \times$ magnification, respectively, in a Jeol JEM-100CX transmission electron microscope. At least 200 cells were counted from. each grid per sample, except for a few samples at the beginning of the lag phase of the batch cultures, 
when at least 50 cells were counted. Cell widths $(W)$ and lengths $(L)$ were measured from the electron micrographs and the volume $(V)$ was calculated according to the formula:

$$
V=\frac{\pi}{4} \cdot W^{2} \cdot\left(L-\frac{W}{3}\right)
$$

FDC was also estimated from 6 DAPIstained samples (see Table 4) so as to allow a comparison of FDC counts obtained by TEM and epifluorescence microscopy. The latter samples $(1 \mathrm{ml})$ were filtered onto black nuclepore filters $(0.2 \mu \mathrm{m})$ and stained according to Porter \& Feig (1980). At least 400 cells and 20 fields were counted from each sample with a Leiz Dialux epifluorescence microscope using ultraviolet excitation light (filter block A2).

Calculations. Conversion factors (CF) for thymidine incorporation rate were calculated using 3 different models. The equation for the integrative method (Fuhrman \& Azam 1980) is:

$$
C F=\frac{N_{f}-N_{0}}{\int_{t=0}^{t=t} \text { TTI d } t}
$$

where $N_{\mathrm{f}}=$ final cell count, $N_{0}=$ initial cell count, $\mathrm{TTI}=$ thymidine incorporation rate and $t=$ time. In the cumulative method (Bjørnsen \& Kuparinen 1991), the conversion factor is the slope of the linear regression of cell abundance on cumulative thymidine incorporation rate:

$$
\text { Cells }=\mathrm{CF}\left(\sum T \mathrm{TI}\right)+b
$$

The modified derivative conversion factor (Ducklow et al. 1992) is calculated from the equation:

$$
C F=\frac{\mu \exp B}{\exp b}
$$

where $\mu=$ cell-number-based growth rate, and $B$ and $b$ are the respective $y$-intercepts of the regression equations for $\log _{e}$-transformed cells and for $\mathrm{TdR}$ on time. The biovolume-based conversion factors were calculated using bacterial biovolume instead of cell numbers.

The equation used to estimate bacterial production from FDC and cell numbers was calculated from the regression between FDC and cell-number-based growth rate (Hagström et al. 1979):

$$
\mu=\mathrm{FDC} \cdot a+b
$$

where $a$ is the slope and $b$ is the $y$-intercept.

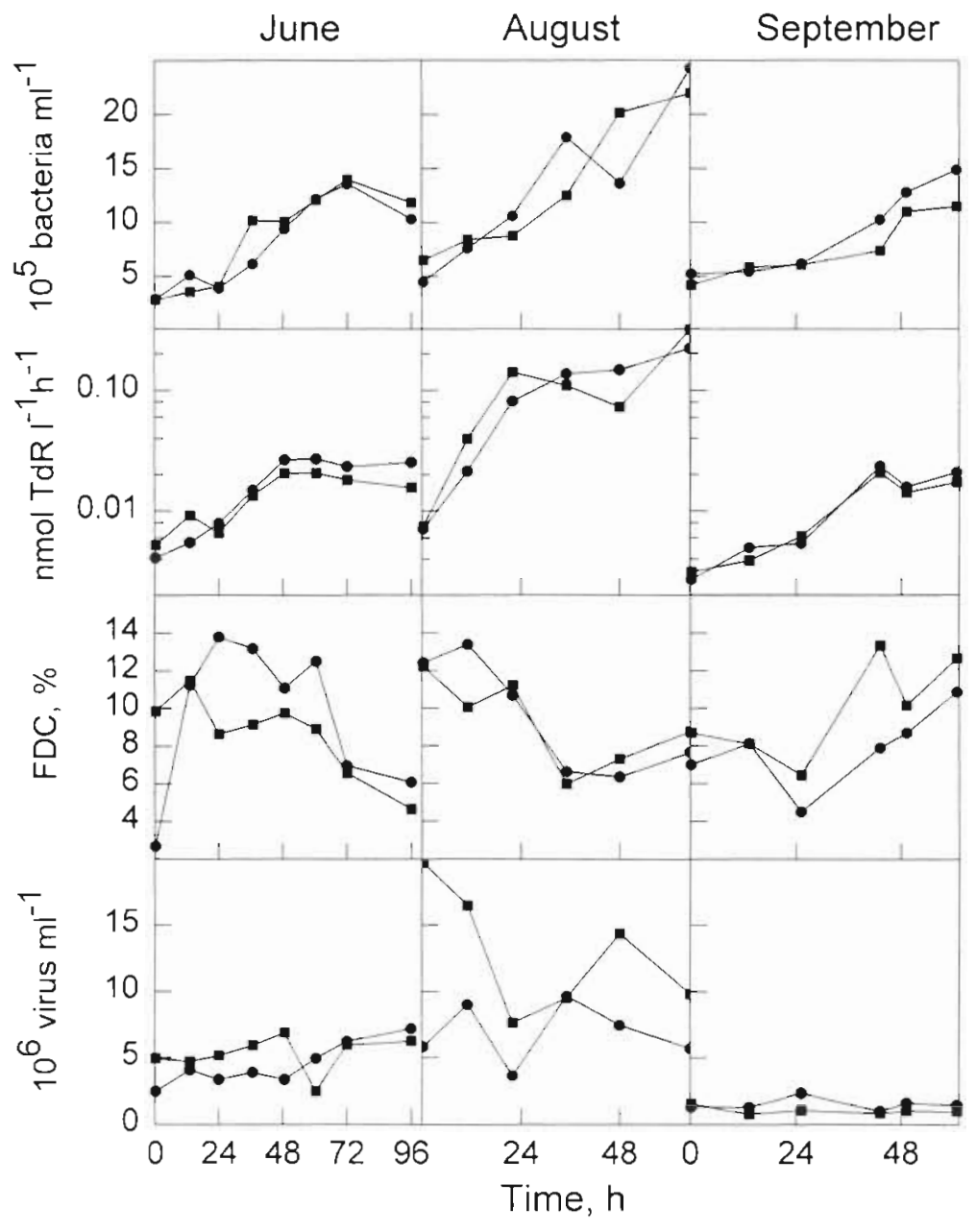

Fig. 2. Bacterial cell counts, thymidine incorporation rate, FDC and abundance of viruses in the replicate batch cultures $(\bullet,-)$ performed on July 21 , August 2 and September 18, 1994.

\section{RESULTS}

\section{Batch cultures}

The electron microscopic counting of evenly distributed bacteria on the specimen grids was done directly from the phosphorescent screen of the TEM. On average, 1 to 4 cells field ${ }^{-1}$ were counted and, according to earlier studies (Tuomi unpubl. results), the possible error of this method is approximately $10 \%$.

The grow th of bacteria in the batch cultures is shown in Fig. 2. In each set of parallel experiments the initial situation was different with respect to the abundance of bacteria, bacterial production and the abundance of viruses. In all experiments TTI increased faster than the cell number The average cell size also increased during the incubations (Table 2). The FDC ranged between 3 and $14 \%$ (Fig. 2).

The abundance of viruses did not increase during the incubations, but varied between the experiments, 
Table 2. Average bacterial cell volumes $\left(\mu \mathrm{m}^{3} ; \mathrm{SD}\right.$ in parentheses) at the beginning and end of the 2 replicate batch cultures, as well as in seawater samples at the time of the experiments. The end values are after 48,65 and $60 \mathrm{~h}$ incubation in the July, August and September experiments, respectively

\begin{tabular}{|lccc|}
\hline Experiment & Start & End & Seawater \\
\hline June & $0.057(0.060)$ & $0.154(0.132)$ & $0.075(0.140)$ \\
August & $0.082(0.101)$ & $0.073(0.077)$ & \\
& $0.049(0.065)$ & $0.158(0.112)$ & $0.077(0.127)$ \\
September & $0.030(0.034)$ & $0.138(0.138)$ & \\
& $0.081(0.078)$ & $0.095(0.114)$ & $0.046(0.061)$ \\
& $0.039(0.033)$ & $0.063(0.061)$ & \\
\hline
\end{tabular}

being $2-7 \times 10^{6} \mathrm{ml}^{-1}$ in June, $4-20 \times 10^{6} \mathrm{ml}^{-1}$ in August, and $1-2 \times 10^{6} \mathrm{ml}^{-1}$ in September (Fig. 2). The virus to bacteria ratio (VBR) was lowest in September $(0.7$ to 4$)$ and ranged from 2 to 30 during the other experiments

\section{Conversion factors}

Conversion factors for TTI were calculated using the integrative (Eq. 1), cumulative (Eq. 2) and modified derivative (Eq. 3) methods. Irrespective of season the integrative method gave the lowest conversion factors $\left(0.21\right.$ to $1.42 \times 10^{18}$ cells $\left.\mathrm{mol}^{-1} \mathrm{TdR}\right)$ while the other methods produced higher values ranging from 0.67 to $7.18 \times 10^{18}$ cells $\mathrm{mol}^{-1}$ TdR (Table 3 ). Biovolume-based conversion factors ranged between 0.31 and $24.34 \times$ $10^{17} \mathrm{\mu m}^{3} \mathrm{~mol}^{-1} \mathrm{TdR}$ (Table 3). The highest values were calculated using the modified derivative method.

The FDC percentages counted with TEM gave values similar to or higher than those determined by epifluorescence microscopy (Table 4). The equation for bacterial growth rate was calculated from the regression line between FDC and the growth rate based on cell numbers (Fig. 3, Table 5). The correlation between

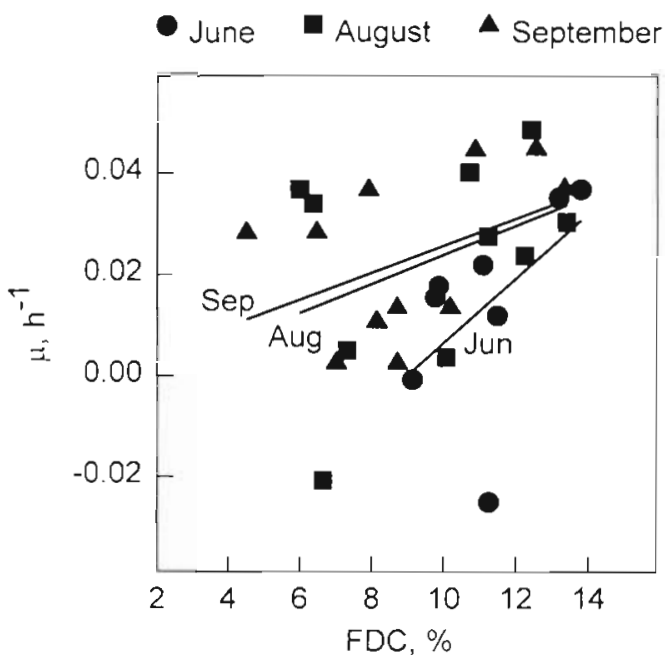

Fig. 3. Regressions between the cell-number-based growth rate $(\mu)$ and FDC during different experiments

FDC and $\mu$ was significant in the August experiment $(\mathrm{r}=0.465, \mathrm{p}=0.02)$, but not in the other experiments or when all the data was pooled $(r<0.05, p>0.1)$. Logarithmic or square-root transformations of the data did not increase the correlation between FDC and $\mu$.

\section{Field study}

The peak of the spring phytoplankton bloom was

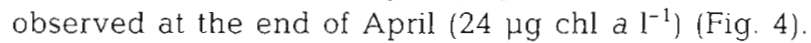
By the middle of May mineral nutrient concentrations were depleted from the productive surface layer $\left(\mathrm{NO}_{3}-\mathrm{N}<5 \mu \mathrm{gl}^{-1}, \mathrm{PO}_{4}-\mathrm{P}<2 \mu \mathrm{g} \mathrm{l}^{-1}\right)$ and the chl a concentration decreased to $1-3 \mu \mathrm{g} \mathrm{l}^{-1}$. An increase in chl a concentration $\left(5 \mu \mathrm{g} \mathrm{l}^{-1}\right)$ was observed again in September.

The FDC and TTI values, which were used to estimate bacterial production, showed similar developments in the field study $(r=0.628, p<0.001)$. In May,

Table 3. Conversion factors from the 2 replicate batch cultures for estimating bacterial cell (10 ${ }^{18}$ cells $\mathrm{mol}^{-1} \mathrm{TdR}$ ) and biovolume $\left(10^{17} \mu^{3} \mathrm{~mol}^{-1} \mathrm{TdR}\right)$ production rates calculated using the integrative, cumulative and modified derivative methods

\begin{tabular}{|c|c|c|c|c|c|c|}
\hline \multirow[t]{2}{*}{ Experiment } & \multicolumn{3}{|c|}{$10^{18}$ cells mol $\mathrm{m}^{-1} \mathrm{TdR}$} & \multicolumn{3}{|c|}{ 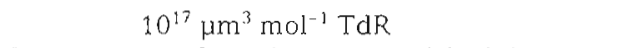 } \\
\hline & Integrative & Cumulative & Modified derivative & Integratuve & Cumulative & Modified derivative \\
\hline \multirow[t]{2}{*}{ June } & 1.24 & 2.80 & 3.32 & - & - & - \\
\hline & 1.42 & 6.40 & 3.02 & 1.36 & - & - \\
\hline \multirow[t]{2}{*}{ August } & 0.28 & 1.15 & 7.18 & 0.51 & 1.37 & 11.10 \\
\hline & 0.21 & 0.67 & 5.60 & 0.31 & 1.10 & 24.34 \\
\hline \multirow[t]{2}{*}{ September } & 1.28 & 5.60 & 5.10 & 1.09 & - & 7.77 \\
\hline & 1.07 & 5.70 & 4.14 & 0.82 & - & 1.83 \\
\hline Average & 0.91 & 3.72 & 4.73 & 0.82 & 1.24 & 11.26 \\
\hline
\end{tabular}


Table 4. FDC counts from transmission electron microscopy (TEM) and epifluorescence microscopy (EF) in the batch cultures

\begin{tabular}{|crc|}
\hline Sample & \multicolumn{2}{c|}{ FDC } \\
& TEM & EF \\
\hline June experiment & & \\
$0 \mathrm{~h}$ & $2.7 \%$ & $3.5 \%$ \\
$49 \mathrm{~h}$ & $11.1 \%$ & $6.9 \%$ \\
$72 \mathrm{~h}$ & $6.9 \%$ & $5.7 \%$ \\
August experiment & $12.4 \%$ & $2.4 \%$ \\
$0 \mathrm{~h}$ & $6.6 \%$ & $6.9 \%$ \\
$35 \mathrm{~h}$ & $7.7 \%$ & $5.0 \%$ \\
$65 \mathrm{~h}$ & & \\
\hline
\end{tabular}

after the collapse of the spring phytoplankton bloom, increased TTI $\left(0.05 \mathrm{nmol} \mathrm{TdR} \mathrm{l}^{-1} \mathrm{~h}^{-1}\right)$, FDC $(11 \%)$, and bacterial cell numbers $\left(3 \times 10^{6} \mathrm{ml}^{-1}\right)$ were observed (Fig. 4). From the middle of June until the beginning of August, TTI values were moderate $(0.01$ to $0.02 \mathrm{nmol}$ TdR $\left.\mathrm{l}^{-1} \mathrm{~h}^{-1}\right)$, FDC ranged from 4 to $8 \%$ and total cell counts varied between 1 and $3 \times 10^{6} \mathrm{ml}^{-1}$. In the beginning of August, when the water temperature in the surface rose to almost $20^{\circ} \mathrm{C}$, TTI increased to $0.06 \mathrm{nmol}$ TdR $\mathrm{l}^{-1} \mathrm{~h}^{-1}, \mathrm{FDC}$ to $11 \%$ and cell numbers to $5 \times$ $10^{6} \mathrm{ml}^{-1}$. In September bacterial activity and cell num-

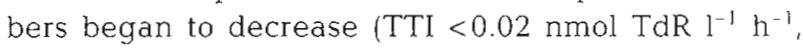
FDC $<6 \%$ and bacterial cell numbers $<2 \times 10^{6} \mathrm{ml}^{-1}$ ). The average cell size of the bacteria varied between 0.06 and $0.11 \mu^{3}$ in the spring (April-May), but decreased toward the end of the study period $\left(0.04 \mu^{3}\right.$ in October).

Virus abundance was $1.5 \times 10^{7} \mathrm{ml}^{-1}$ at the beginning of April, increased to $5.9 \times 10^{7} \mathrm{ml}^{-1}$ at the end of April, and varied between 1 and $4 \times 10^{7} \mathrm{ml}^{-1}$ in May-July. The highest virus numbers were observed in August $\left(14 \times 10^{7} \mathrm{ml}^{-1}\right)$. During the height of the phytoplankton bloom in spring, VBR was ca 60 , but otherwise the ratio remained between 10 and 30 . VBR increased again slightly in September-October

\section{Bacterial carbon production in the field}

Bacterial carbon production was estimated from the surface layer $(0$ to $5 \mathrm{~m}$ ) of the fixed sampling station from June 7 to October 5. The empirical conversion factors and cell volumes determined in this study were used. The literature value for bacterial cell carbon content, $1 \times 10^{-13} \mathrm{~g} \mathrm{\mu m}^{-3}$, had been measured from the study area using $X$-ray microanalysis (Fagerbakke et al. 1996).

The field data was divided into 3 periods: June 7 to July 26, July 26 to August 31, and August 31 to October 5 . The average of the conversion factors measured

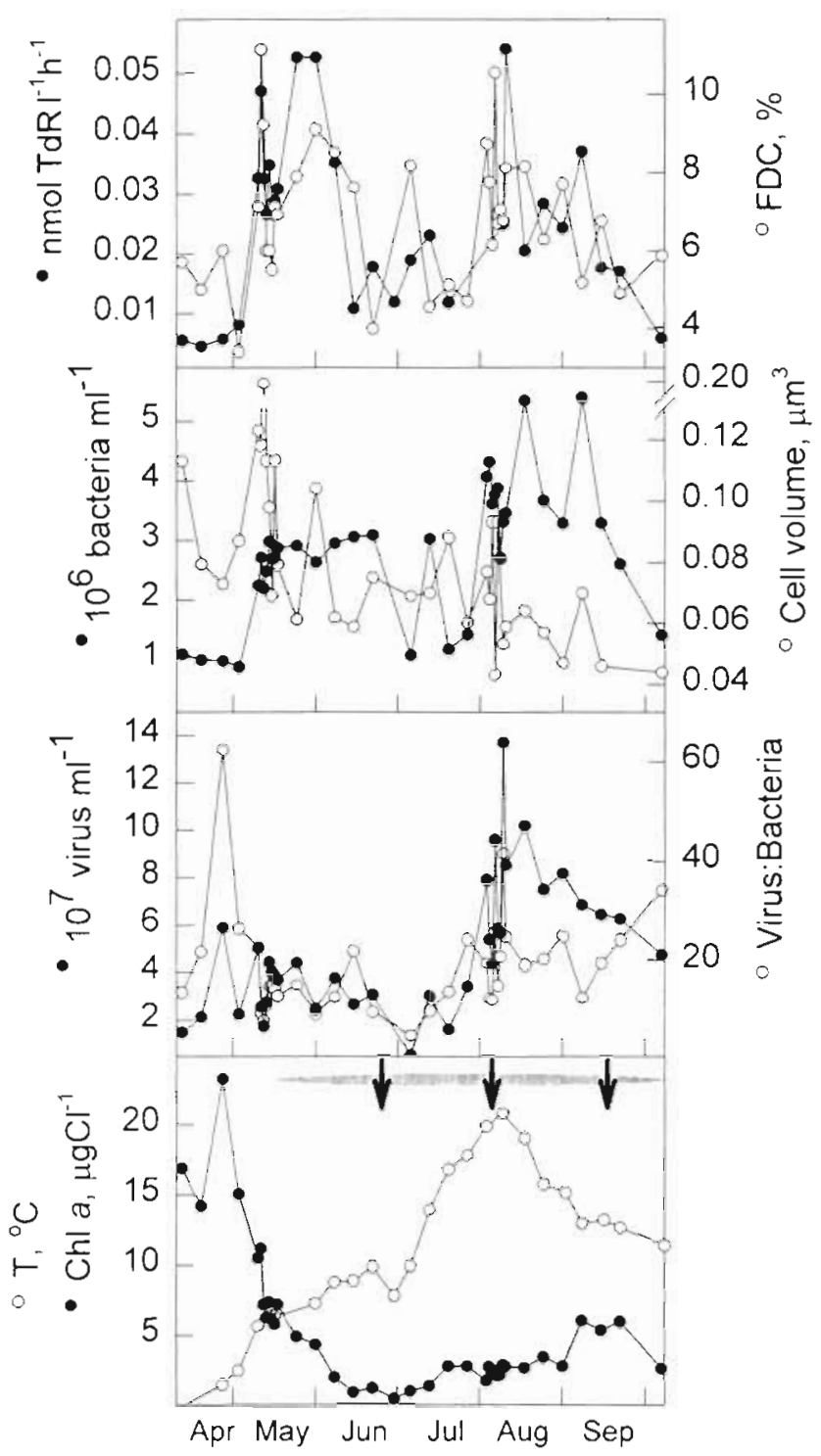

Fig. 4. Thymidine incorporation rate, FDC, bacterial abundance, cell volumes, virus abundance, virus to bacteria ratio, temperature and chl a concentration in the upper $5 \mathrm{~m}$ at the monitoring station at the entrance to the Gulf of Finland in 1994 The dates for conversion factor experiments are shown by arrows. The gray stripe shows the period when the water column was well stratified

Table 5. Growth rate equations $\left(\mu, \mathrm{h}^{-1}\right)$ based on FDC $(\%)$, calculated from different batch cultures

\begin{tabular}{|lc|}
\hline Experiment & Equation \\
\hline June & $\mu=0.006 \mathrm{FDC}+0.057$ \\
August & $\mu=0.003 \mathrm{FDC}-0.005$ \\
September & $\mu=0.003 \mathrm{FDC}-0.001$ \\
All data & $\mu=0.002 \mathrm{FDC}-0.001$ \\
\hline
\end{tabular}


Table 6. Bacterial carbon production estimates, calculated using different methods, in the upper $5 \mathrm{~m}$ at the fixed monitoring station in 1994 (June 7 to October 5)

\begin{tabular}{ll|}
\hline & $\mathrm{g} \mathrm{C} \mathrm{m}^{-2}$ \\
\hline TTi-based estimates, when the conversion & \\
factor was calculated using: & \\
cell numbers and: & 1.6 \\
- the integrative method & 6.5 \\
- the cumulative method & 7.4 \\
- the modified derivative method & \\
biovolumes and: & 4.0 \\
- the integrative method & 9.5 \\
FDC-based estimate & \\
\hline
\end{tabular}

during each period (Table 3 ) or the equation derived for $\mu$ from FDC (Table 5) was applied to the data from that same period. As no conversion factor was measured during the spring, the period from April to June was not included in the comparison. The biovolumebased estimate was calculated with the conversion factors using the integrative method Conversion factors calculated using Eqs. (2) \& (3) gave higher bacterial carbon production estimates than the conversion factor calculated with Eq. (1). The FDC-based estimate was higher than the bacterial carbon production estimates based on TTI (Table 6).

\section{DISCUSSION}

\section{Conversion factors for thymidine incorporation rate}

The empirical conversion factors for TTI varied between the experiments and depending on the calculation method, but were similar to the average conversion factors reported earlier for the study area 10.6 to $4.94 \times 10^{18}$ cells $\mathrm{mol}^{-1} \mathrm{TdR}$; Kuparinen 1988, Autio 1990, 1992, Kuuppo-Leinikki \& Kuosa 1990, Heinänen \& Kuparinen 1992). Experiments in this study were performed at different times of the year, when temperature, nutritional conditions and probably also bacterial community composition were different in each set of the 2 parallel batch cultures. Bacterial strains may vary in their thymidine incorporation ability (Jeffrey \& Paul 1990), but the effect of different bacterial assemblages remained unexplored in this study. The trophic state of the environment has been suggested to explain the variation between the conversion factors (e.g. Iriberri et al. 1990). On the other hand, nutrient additions or temperature did not affect conversion factors when studied by Riemann et al. (1987), Autio (1990) and Heinänen \& Kuparinen (1992). In general, published empirical conversion factors from different envi-

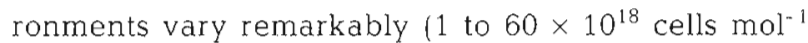
$\mathrm{TdR}$; references in Bell 1988). As long as this variation cannot be predicted, conversion factors need to be determined for each new situation in a field study.

The growth pattern - the increase in cell numbers versus TTI - is critical, and different calculation methods give different weight to the above mentioned parameters. In all experiments of this study TTI increased faster than cell numbers, resulting in different conversion factors from the same data when calculated using different methods. The conversion factor values calculated with the integrative method were always lower when compared to those calculated using the other methods (Table 3). This may be attributed to the different calculation approach, i.e. the total amount of cells produced and thymidine incorporated during a certain time period, as compared to the use of a regression line as an estimate of the one, or both, parameters in the other methods. On average, the conversion factor values calculated using the modified derivative or cumulative method did not differ significantly (median test, $\mathrm{p}=0.248$ ), although in the August experiment the modified derivative method gave 7 times higher values than the cumulative calculation method.

In the August and September experiments, the TTI per cell and the average cell size of bacteria increased during the incubation (Table 2). It is possible that the incorporation of thymidine into macromolecules other than DNA had increased, which would have led to the underestimation of the conversion factors. Furthermore, in the August experiment the number of viruses was higher than in other experiments and lysis of the cells may partly explain the discrepancy between the TTI and cell numbers. The virus to bacteria ratio, which was as high as in the seawater samples, indicates possible virus-induced mortality of bacteria in the culture.

\section{Conversion equation for FDC}

The FDC, counted with TEM, varied between 3 and $14 \%$, which is within the same range as that which has been observed by epifluorescence microscopy in other studies (e.g Newell \& Christian 1981). In this study, some of the samples were counted using both TEM and epifluorescence microscopy, yet the especially high FDC values (>10\%) counted with TEM were not found with epifluorescence microscopy (Table 4). This discrepancy is probably due to the better resolution of TEM, which makes it easier to find the dividing cells compared to the epifluorescence technique.

Bacterial growth rate and FDC were not correlated in the batch cultures (Fig. 3), except for the August experiment $(r=0.465)$. A better correlation was found by Hagström et al. (1979), when the bacterial growth 
rates were higher ( $\mu=0.02$ to $0.2 \mathrm{~h}^{-1}$ ) than in this study $\left(\mu<0.08 \mathrm{~h}^{-1}\right)$ Consequently, a wider range of growth rates may be needed to better relate $\mu$ and FDC. The discrepancy between FDC and the growth rate may be partly explained by the cells remaining together after their division, or by division induced through starvation. Furthermore, bacterial mortality due to viral infection may have occurred in the batch cultures, which would have affected the bacterial growth rates calculated from the cell abundances.

\section{The field study}

In the field study FDC was significantly correlated to TTI $(r=0.628, p<0.001)$, which indicates that FDC is a potential parameter for measuring bacterial activity. In different seasons separate conversion factors for TTI should be determined, as the bacterial community, as well as its environment, may vary and affect the uptake and incorporation of labeled thymidine. The conversion factors for TTI and the equations for estimating $\mu$ from FDC presented in this study were used to estimate bacterial carbon production in the upper $5 \mathrm{~m}$ of the Gulf of Finland between June 7 and October 5 in 1994 (Table 6). Bacterial carbon content used in this study was measured by X-ray microanalysis from the study area in July 1993, but the use of one value for the whole study may have introduced some error in the bacterial carbon production estimates (Fagerbakke et al. 1996). The lowest bacterial carbon production estimate, which was obtained using the conversion factors calculated with the integrative method to transform TTI to the cell production rate, was only $4 \%$ of the primary production in the same water layer (acidified whole ${ }^{14} \mathrm{C}$-samples, $24 \mathrm{~h}$ in situ bottle incubations covering the euphotic layer. R. Lignell pers. comm.). The bacterial carbon production estimates using the other methods ( 10 to $23 \%$ of the primary production) were in better agreement with an earlier study from the same area (bacterial production $14 \%$ of the primary production; Lignell 1990) and with a cross-system overview (bacterial production $20 \%$ of the primary production; Cole et al. 1988).

The average cell volume of bacteria varied from 0.044 to $0.197 \mathrm{\mu m}^{3}$ over the productive season, showing a cell size decrease towards the autumn. The same trend can be found when comparing earlier published cell volumes of bacteria from the Gulf of Finland (Kuparinen 1988, Heinänen 1991, Heinänen \& Kuparinen 1991). Consequently, the use of only one value for the cell volume for the whole productive season would introduce an error into bacterial carbon production estimates. With the use of a biovolume- instead of the cell-number-based conversion factor the need for determining cell volumes in a field study is avoided. Using the integrative calculation method the biovolume-based estimate of bacterial carbon production was 2.5 times higher than the cell-number-based estimate (Table 6). Using the other calculation methods the biovolume-based conversion factors gave 3 to 5 times higher production estimates when compared to the cell-number-based conversion factors for the field data in August (data not shown). Selective grazing on large cells decreases the average bacterial cell size in the plankton ecosystem (Kuuppo-Leinikki 1990), resulting in an underestimate of the total bacterial carbon production when the cell-number-based conversion factor and the average cell volume are used.

The virus abundance followed the bacterial abundance in the weekly samples during the field study. Bacterial mortality by viral lysis in the Gulf of Finland was probably as significant as in other aquatic environments (as much as $66 \%$ of total bacterial mortality), with similar virus to bacteria ratios (2 to 60) (Steward et al. 1992, Fuhrman \& Noble 1995, Hennes \& Simon 1995. Mathias et al. 1995). The quick changes in viral counts within a short time (2- to 4 -fold increase within 10 to 20 min) (Bratbak et al. 1996) indicate that viralinduced mortality may occasionally be very high. Any effect of viral lysis on bacterial production estimates was not evident in this study. Assuming that on average there are $10^{\mathrm{h}}$ bacteria $\mathrm{ml}^{-1}$, and $10^{7}$ viruses $\mathrm{ml}^{-1}$ in the planktonic ecosystem, that $40 \%$ of the viruses exhibit decay at a rate of $0.07 \mathrm{~h}^{-1}$, and that the average burst size is 55 (author's unpubl. results), then less than $0.5 \%$ of bacteria would be lysed within $1 \mathrm{~h}$, which was the maximum incubation time in the bacterial production measurements. Consequently, viruses will not affect bacterial production estimates, if the incubation conditions do not increase viral activity. However, viruses are also present in batch cultures when empirical. conversion factors are determined, and it is not known whether viral-induced mortality is already included in the factors. This would mean that in the field it is net bacterial production after viral lysis that is actually measured. Virus-induced mortality of bacteria in batch cultures may partly explain the variation in conversion factor values.

\section{CONCLUSIONS}

Bacterial production estimates using TTI and FDC were on the same order of magnitude in the study area. The major advantage of the FDC method is that it does not require incubation of samples, which may cause unwanted changes during the measurement, but the lack of correlation between $\mu$ and FDC showed that FDC is not an accurate estimate of bacterial growth 
rate. Even in the same study area, conversion factors for thymidine incorporation rate vary remarkably between the different seasons. The conversion factors using the modified derivative and cumulative calculation methods gave similar bacterial production estimates, while the integrative method seemed to underestimate bacterial production. Also, the average cell size of bacteria vary among the seasons, but the cell volumes can already be included in the conversion factor and thus the production of bacterial biovolume will be measured.

Acknowledgements. This study was carried out under the research project PELAG at the Tvarminne Zoological Station University of Helsinki. The whole PELAG team is thanked for their help and for providing background data. Electron mucroscopy was done at the Department of Electron Microscopy, University of Helsinki. The English was revised by Maria Ekman-Ekebom (MSc).

\section{LITERATURE CITED}

Autio RM (1990) Bacterioplankton in filtered brackish water cultures: some physical and chemical parameters affecting community properties. Arch Hydrobiol 117:437-451

Autio RM (1992) Temperature regulation of brackish water bacterioplankton. Arch Hydrobiol Beih Ergeb Limnol 37 $253-263$

Bell RT (1988) Thymidine incorporation and estimates of bacterioplankton production: are the conversion factors valid? Arch Hydrobiol Beih Ergeb Limnol 31:163-171

Bjørnsen PK, Kuparinen J (1991) Determination of bacterioplankton biomass, net production and growth efficiency in the Southern Ocean. Mar Ecol Prog Ser 71:185-194

Bratbak G. Heldal M (1993) Total count of viruses in aquatic environments. In: Kemp PF, Sherr BF, Sherr EB, Cole JJ (eds) Handbook of methods in aquatic microbial ecology. Lewis Publishers, Boca Raton, FL, p 135-138

Bratbak G, Heldal M, Thingstad TF, Tuomi P(1996) Dynamics of virus abundance in coasial water. FEMS Microbiol Ecol 19:263-269

Cole JJ, Findlay S, Pace ML (1988) Bacterial production in fresh and saltwater ecosystems; a cross-system overview. Mar Ecol Prog Ser 43:1-10

Ducklow HW, Kirchman DL, Quinby HL (1992) Bacterioplankton cell growth and macromolecular synthesis in seawater cultures during the North Atlantic spring phytoplankton bloom, May, 1989. Microb Ecol 24:125-144

Fagerbakke KM, Heldal M, Norland S (1996) Content of carbon, nitrogen, oxygen, sulfur and phosphorus in native aquatic and cultured bacteria. Aquat Microb Ecol 10:15-27

Fuhrman J, Azam F (1980) Bacterioplankton secondary production estimates for coastal waters of British Columbia, Antarctica, and California. Appl Environ Microbiol 39:1085-1095

Fuhrman J, Azam F (1982) Thymidine incorporation as a measure of heterotrophic bacterioplankton production in marine surface waters: evaluation and field results. Mar Biol 66:109 -120

Fuhrman JA, Noble RT (1995) Viruses and protists cause similar bacterial mortality in coastal seawater. Limnol Oceanogr 40:1236-1242

This article was submitted to the editor
Hagström A, Larsson U, Hörstedt P, Normark S (1979) Frequency of dividing cells, a new approach to the determination of bacterial growth rates in aquatic environments. Appl Environ Microbiol 37:805-812

Heinänen A (1991) Bacterial numbers, biomass and productuvity in the Baltic Sea: a crusse study. Mar Ecol Prog Ser $70: 283-290$

Heinànen A, Kuparinen J (1991) Horizontal variation of bacterioplankton in the Baltic Sea. Appl Environ Microbiol 57: 3150-3155

Heinänen A, Kuparinen J (1992) Response of bacterial thymidine and leucine incorporation to nutrient $\left(\mathrm{NH}_{4}, \mathrm{PO}_{4}\right)$ and carbon (sucrose) enrichment. Arch Hydrobiol Beih Ergeb Limnol 37:241-251

Hennes KP, Simon M (1995) Significance of bacteriophages for controlling bacterioplankton growth in a mesotrophic lake. Appl Environ Microbiol 61:333-340

Iriberri J, Unanue M. Ayo B, Barcina I, Egea L (1990) Bacterial production and growth rate estimation from $\left({ }^{3} \mathrm{H}\right)$ thymidine incorpration for attached and free-living bacteria in aquatic systems. Appl Environ Microbiol 56: $483-487$

Jeffrey W, Paul JH (1990) Thymidine uptake, thymidine incorporations, and thymidine kinase activity in marine bacterium isolates. Appl Environ Microbiol 56:1367-1372

Kirchman D, Hugh D, Ralph M (1982) Estimates of bacterial growth from changes in uptake rates and biomass. Appl Environ Microbiol 44:1296-1307

Kuparinen J (1988) Development of bacterioplankton during winter and early spring at the entrance to the Gulf of Finland, Baltic Sea. Verh Internat Verein Limnol 23: $1869-1878$

Kuuppo-Leinikki P (1990) Protozoan grazing on planktonic bacteria and its impact on bacterial population. Mar Ecol Prog Ser 63:227--238

Kuuppo-Leinikki P, Kuosa H (1990) Estimation of flagellate grazing on bacteria by size fractionation in the Northern Baltic Sea. Arch Hydrobiol Beih Ergeb Limnol 34: 283-290

Lignell R (1990) Excretion of organic carbon by phytoplankton: its relation to algal biomass, primary productivity and bacterial secondary productivity in the Baltic Sea. Mar Ecol Prog Ser 68:85-99

Marker AFH, Nusch EA, Rai H, Riemann B (1980) The measurement of photosynthetic pigments in freshwaters and standardization of methods: conclusions and recommendations. Arch Hydrobiol Beih Ergeb Limnol 14:91-106

Mathias CB, Kirschner AKT, Velimrov B (1995) Seasonal variations of virus abundance and viral control of the bactenal production in a backwater system of the Danube River. Appl Environ Microbiol 61:3734-3740

Newell SY, Christian RR (1981) Frequency of dividing cells as an estimator of bacterial productivity. Appl Environ Microbiol 42:23-31

Porter KG, Feig YS (1980) The use of DAPI for identifying and counting aquatic microflora. Limnol Oceanogr 25 : 943-948

Riemann B, Bjørnsen PK, Newell S, Fallon R (1987) Calculation of cell production of coastal marine bacteria based on measured incorporation of $\left({ }^{3} \mathrm{H}\right)$ thymidine. Limnol Oceanogr 32:471-476

Steward GF, Wikner J, Cochlan WP, Smith DC, Azam F (1992) Estimation of virus production in the sea. II. Field results. Mar Microb Food Webs 6:79-90

Manuscript first received: May 28, 1996

Revised version accepted: May 9, 1997 